\title{
The Effect of Nepheline Syenite Addition on Sanitaryware Body
}

\author{
Nazım Kunduracı and Tuna Aydın \\ Canakc1lar Ceramic Co., Gökçebey, Zonguldak, 67670 Turkey. \\ Metallurgy \& Material Engineering Department, Kirikkale University, Kirikkale, 71451 Turkey \\ Phone: +90 (318) 357-4242; Fax: +90 (318) 357-2459, tunaaydin@kku.edu.tr, \\ n.kunduraci@creavit.com.tr
}

\begin{abstract}
The effect of the addition of Nepheline syenite on the sintering, and properties of a sanitaryware porcelain body was studied. Two ceramic bodies were compared: a commercial sanitaryware body and one, where $40 \%$ of the mass of $\mathrm{Na}$ feldspar was substituted nepheline syenite. The sintering was evaluated by the linear shrinkage, the water absorption. Samples, sintered at 1220 and $1190{ }^{\circ} \mathrm{C}$, were used for the evaluation of the the bending strength. The addition of Nepheline syenite had a positive effect on the formation of the liquid phase during the sintering. The sintering and the mechanical properties were improved by heat treatment in the $1190^{\circ} \mathrm{C}$ range.
\end{abstract}

Index Terms—Nepheline cyanide, sintering, sanitaryware, ceramic

\section{INTRODUCTION}

anitaryware is a division of ceramic wares. It is made using clay, quartz and feldspar. Sanitarywares a non-porous ceramic material are fired at temperature ranging from 1200 to $1300^{\circ} \mathrm{C}$ [1]. Today, porcelain is produced in many countries and its technology is well known and described in different textbooks and papers [1-3]. However, the optimization of the sanitaryware porcelain productions is still ongoing and many new works, discussing the ceramic structure or the improvement of its properties, are published every year.

Most of the new studies are related to the substitution of the traditional raw materials in the composition (sand, feldspar and kaolin) with others, such as zeolite, spodumene, waste materials, etc. [4]. The present work investigates the effect of the addition of nepheline syenite on sanitaryware porcelain. Nepheline syenite is a light-colored, medium- to coarsegrained holocrystalline, silica-deficient, feldspathic, plutonic igneous rock largely made up of nepheline, sodium feldspar (albite), and alkali feldspar (orthoclase, microcline), but no quartz. Nepheline syenites are essentially syenites that are undersaturated in silica. Crystallizing from magma undersaturated in silica results in the formation of nepheline

instead of albite feldspar [5].

In this study, two ceramic compositions are compared: a typical commercial composition of kaolin, sand and feldspar and second one, where part of the sand and part of the feldspar were substituted by nepheline syenite.

\section{MATERIALS AND METHODS}

Sanitaryware body compositions were prepared using clay, kaolin, quartz and feldspar. The chemical compositions of these raw materials were determined by X-ray fluorescence (XRF) analyzer (Rigaku, ZSX Primus). A formulation used for industrial production was selected as the standard body (ST) composition. Composition consisting of nepheline syenite was named as (NC). The mixture of raw materials was ground in a ball mill with alumina balls for $7 \mathrm{~h}$. The particle size distribution of the mixture was measured using a laser particle size analyzer (Malvern, Hydro 2000G). The mean particle size of the ST and NC was $17.4 \mu \mathrm{m}$. The liter weight of ST and NC slips were measured by using a pycnometer and was held at $1800 \mathrm{~g} / \mathrm{L}$. Viscosity of slips were measured by using Fordcup. Thixotropy value was measured by using Torsion viscometer (Gallenkamp type). The samples were prepared by using the slip casting method in plaster mould in order to measure deformation, strength, firing shrinkage, water absorption and Harcourt analysis. After shaping samples were dried at $110^{\circ} \mathrm{C}$ for 1 hour. All samples were fired under the industrial conditions. Standard sanitaryware body (ST) was fired at $1220^{\circ} \mathrm{C}$ and $\mathrm{NC}$ body was fired at $1190^{\circ} \mathrm{C}$ for 14 hour.

\section{RESULTS}

Chemical compositions of raw materials were given in Table I and Table II. Rational analyses of raw material were given in Table III. As seen on rational analysis, there was an increase in amount of total feldspar with the addition of nepheline syenite. 
TABLE I

CHEMICAL COMPOSITIONS OF RAW MATERIALS

\begin{tabular}{cccccc} 
& $\mathrm{Lol}$ & $\mathrm{SiO}_{2}$ & $\mathrm{Al}_{2} \mathrm{O}_{3}$ & $\mathrm{Fe}_{2} \mathrm{O}_{3}$ & $\mathrm{TiO}_{2}$ \\
\hline Albite & 0.39 & 69.96 & 17.84 & 0.16 & 0.19 \\
Quartz & 2.02 & 89.94 & 5.6 & 0.62 & 1.02 \\
Kaolin 1 & 9.02 & 64.71 & 24.21 & 0.64 & 0.34 \\
Clay 1 & 10.30 & 56.40 & 29.59 & 1.85 & 1.13 \\
Clay 2 & 10.15 & 56.78 & 27.18 & 1.97 & 1.20 \\
& & & & & \\
Kaolin 2 & 11.40 & 48.02 & 36.01 & 1.02 & 0.06 \\
Nefheline & 0.78 & 56.9 & 23.86 & 1.12 & 0.01 \\
Syenite & & & & &
\end{tabular}

TABLE II

CHEMICAL COMPOSITIONS OF RAW MATERIALS

\begin{tabular}{cccccc} 
& $\mathrm{CaO}$ & $\mathrm{MgO}$ & $\mathrm{Na}_{2} \mathrm{O}$ & $\mathrm{K}_{2} \mathrm{O}$ & $\mathrm{SO}_{3}$ \\
\hline Albite & 0.57 & 0.26 & 9.92 & 0.41 & - \\
Quartz & - & - & 0.24 & 0.16 & - \\
& & & & & \\
Kaolin 1 & 0.09 & 0.05 & 0.08 & 0.21 & 0.47 \\
& & & & & \\
Clay 1 & 0.26 & 0.48 & 0.21 & 1.59 & \\
Clay 2 & 0.19 & 0.57 & 0.19 & 1.61 & 0.06 \\
Kaolin 2 & 0.07 & 0.40 & 0.13 & 2.73 & - \\
$\begin{array}{c}\text { Nefheline } \\
\text { Syenite }\end{array}$ & 1.34 & 0.03 & 9.58 & 6.37 & - \\
\hline
\end{tabular}

TABLE III

RATIONAL ANALYSES

\begin{tabular}{ccccc}
\multicolumn{5}{c}{ RATIONAL ANALYSES } \\
& $\begin{array}{c}\text { K- } \\
\text { feldspar }\end{array}$ & $\begin{array}{c}\text { Sodium } \\
\text { feldspar }\end{array}$ & Kaolin & Quartz \\
\hline NC & 16.37 & 32.21 & 35.40 & 16.02 \\
ST & 5.93 & 26.73 & 43.78 & 23.56 \\
\hline
\end{tabular}

\section{RESULTS}

Rheological properties of slips were given in Table IV. The liter weight of slips kept constant at $1800 \mathrm{~g} / \mathrm{L}$. There were decreases in viscosity and thixotropy values with the addition of nepheline syenite. Thickness rate is the most important property of sanitaryware slip. After casting water is absorbed by the plaster mold with capillary force. As time progress an area in the shape of the plaster mold was shaped with a suitable solid-liquid properties. The thickness of this area increases at a decreasing rate in time. Thickness rate should be as high as possible for a good casting. Although viscosity and thixotropy values decreases, there was not any negative effect on the thickness rate of slip with the addition of nepheline syenite instead of sodium feldspar. Drying shrinkage, firing shrinkage and total shrinkage values were in Table V. There was not any change for firing shrinkage with the addition of nepheline syenite. However there were slightly decreases in drying shrinkage and total shrinkage with the addition of nepheline syenite. Dry strength, firing strength and water absorption values were given in Tale VI. There were increases in drying and firing strength of the bodies with the nepheline syenite addition instead of sodium feldspar. Deformation is one of the most important properties of sanitaryware bodies. The first deformation is observed during drying process and the second deformation is observed during firing. In Table VI, firing deformation values were given. It was determined that there were increases in deformation with the addition of nepheline syenite.

TABLE IV

CHEMICAL COMPOSITIONS OF RAW MATERIALS

\begin{tabular}{|c|c|c|c|c|}
\hline & $\begin{array}{c}\text { Liter } \\
\text { weight } \\
\text { (g/ L ) }\end{array}$ & $\begin{array}{l}\text { Viscosity } \\
\text { (cp) }\end{array}$ & $\begin{array}{c}\text { Thixotr opy } \\
\left.\mathbf{(}^{\mathbf{o}}\right)\end{array}$ & $\begin{array}{c}\text { Thickness } \\
\text { rate } \\
(\mathrm{mm} / 1 \\
\text { hour) }\end{array}$ \\
\hline ST & 1800 & 550 & 55 & 7.8 \\
\hline $\mathrm{NC}$ & 1800 & 431 & 50 & 7.7 \\
\hline
\end{tabular}

TABLE V

DRYING SHRINKAGE, FIRING SHRINKAGE AND TOTAL SHRINKAGE

\begin{tabular}{|c|c|c|c|}
\hline & $\begin{array}{c}\text { Drying } \\
\text { Shrinkage (\%) }\end{array}$ & $\begin{array}{l}\text { Firing shrinkage } \\
\qquad(\%)\end{array}$ & $\begin{array}{c}\text { Total } \\
\text { shrinkage } \\
(\%)\end{array}$ \\
\hline ST & 2.5 & 8 & 10.5 \\
\hline NC & 2.1 & 8 & 10.1 \\
\hline
\end{tabular}


TABLE VI

DRY STRENGTH, FIRING STRENGTH, WATER ABSORPTION

\begin{tabular}{|c|c|c|c|}
\hline $\begin{array}{c}\text { Dry } \\
\text { strength } \\
\mathrm{kg} / \mathrm{cm}^{2}\end{array}$ & $\begin{array}{c}\text { Firing } \\
\text { strength } \\
\mathrm{kg} / \mathrm{cm}^{2}\end{array}$ & $\begin{array}{c}\text { Water } \\
\text { absorption } \\
(\%)\end{array}$ & $\begin{array}{c}\text { Firing } \\
\text { defor mation } \\
(\mathrm{mm})\end{array}$ \\
\hline
\end{tabular}

ST

$31.25 \quad 340$

0.1

23

NC

32

341

0.01

30

Harkort testing was done in order to the choice of an adequate glaze for biscuit. It requires knowledge of the basic characteristics of glazes as well as of the biscuit, mainly the firing temperature of the glaze, the dilatation curve of the biscuit and of the glaze below Tg temperature (transformation point of glass). The match of dilatation behavior between biscuit and glaze is a basic and unavoidable requirement so that tensile and/or compression stress is not originating in the glaze during cooling in the end of firing process. Tensile and higher compression stress in the glaze releases via cracks forming. The number and shape of the cracks in the glaze is dependent on the value of thermal expansion coefficient difference between biscuit and glaze, also on glaze coat thickness (usual $150-250 \mu \mathrm{m}$ ), on nature of glaze-biscuit interface which forms during the firing, on the firing quality of the glaze and on the cooling rate [,]. Maximum withstanding temperature of glaze and bodies without crazing (cracking) were given in Table VII. It was determined that while glaze and body of standard sample withstand up to $190^{\circ}$, glaze and body of nepheline sample withstand up to $210^{\circ}$.

TABLE VII

HARKORT TESTING

Glaze

Slip

ST

Maximum $190^{\circ}$

Maximum $190^{\circ}$

NC

Maximum $210^{\circ}$

Maximum $210^{\circ}$
Microstructural properties of fired samples were analyzed by using SEM-EDX techniques. The microstructural properties of the bodies can be seen in Fig. 1 and Fig. 20. As seen on micrograph the crystalline mullite and quartz phases were dispersed in a glassy matrix. Needle-like secondary mullite crystals and primary mullite crystals were also seen in Fig. 2.

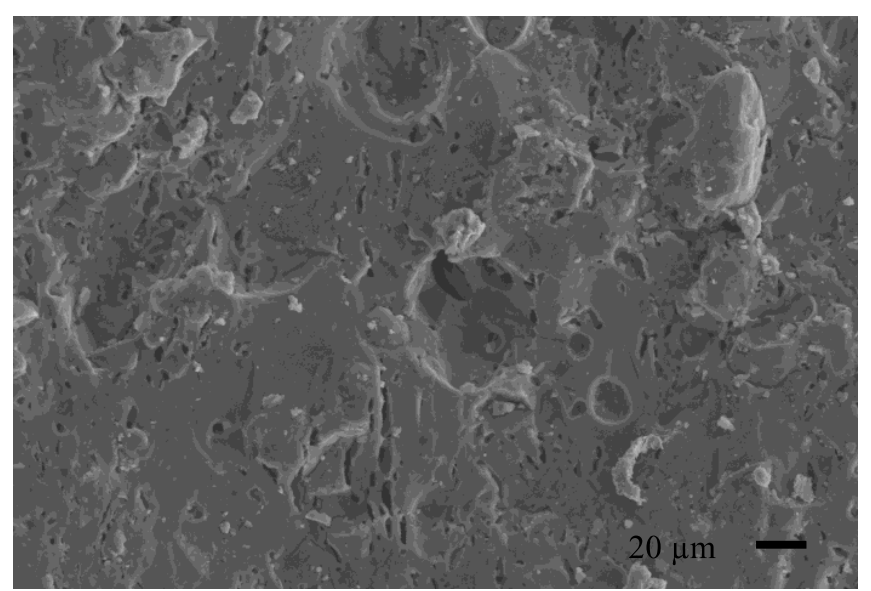

Fig 1. Microstructure of the standard sanitaryware body (ST).

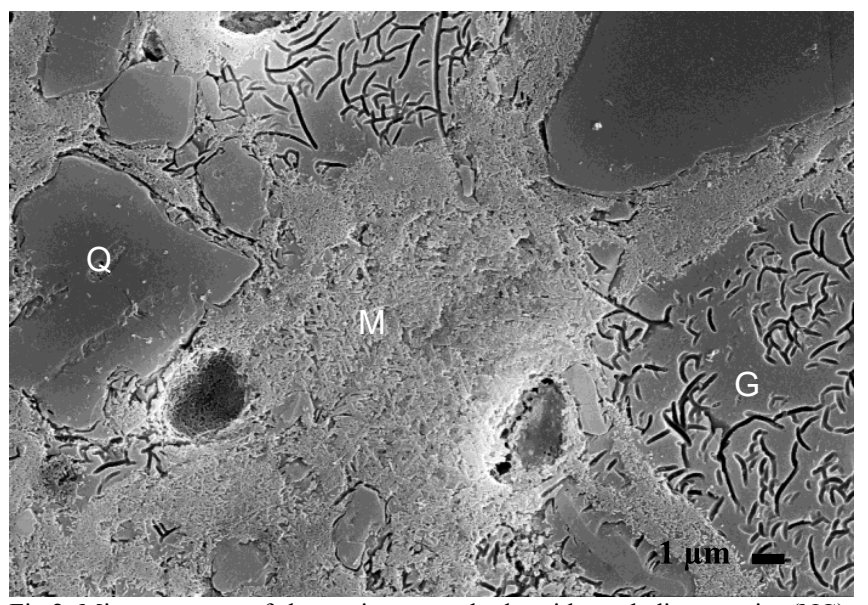

Fig 2. Microstructure of the sanitaryware body with nepheline syenite (NC), Q: Quartz, M: Mullite and G: Glassy phase.

\section{CONCLUSION}

In this paper, we have developed sanitaryware body consisting of nepheline syenite. Two ceramic bodies were compared: a commercial sanitaryware body and one, where $40 \%$ of the mass of Na feldspar was substituted nepheline syenite. The addition of nepheline syenite provided decreasing total shrinkage, water absorption. According to Harkort testing, samples consist of nepheline syenite (NC) withstood up to $210^{\circ} \mathrm{C}$.

In conclusion, the addition of $40 \%$ nepheline syenite reduces the sintering interval, decreases the sintering temperature $\left(1190^{\circ} \mathrm{C}\right)$ and helps to obtain better mechanical properties (dry and firing strength). 


\section{REFERENCES}

[1] W.D. Kingery, Introduction to Ceramics, J.Wiley \& Sons, New York, 1976.

[2] J.S. Reed, Principles of Ceramic Proc eedings, J. Wiley \& Sons, New York, 1995.

[3] W.M. Carty, U. Senapati, Porcelain — raw materials, processing, phase evolution, and mechanical behavior, J. Am. Ceram. Soc. Vol. 81 (1) pp. 3-20, 1998

[4] T.Aydın, A.Kara, "Effect of spodumene addition on pyroplastic deformation of porcelain stoneware" Journal of Ceramic Processing Research. Vol. 15, No. 6, pp. 486-491, 2014

[5] P.W. Harben, The Industrial Minerals Handy Book: A Guide to Markets, Specifications and Prices. 4th edition. London: Industrial Minerals Information 2002 